JOURNAL OF SECURITY AND SUSTAINABILITY ISSUES

ISSN 2029-7017 print/ISSN 2029-7025 online

2020 June Volume 9 Number 4

http://doi.org/10.9770/jssi.2020.9.4(22)

Scopus ${ }^{\circ}$

\title{
ENGAGEMENT WITH ONLINE MEDIA
}

\author{
Somdech Rungsrisawat ${ }^{1}$, Thitinan Chankoson ${ }^{2}$ \\ ${ }^{1}$ Suan Sunandha Rajabhat University, Bangkok, Thailand \\ ${ }^{2}$ Faculty of Business Administration for Society, Srinakharinwirot University, Bangkok, Thailand

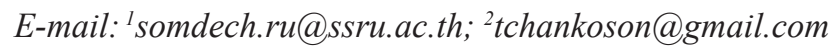

Received 20 June 2019; accepted 28 April 2020; published 30 June 2020

\begin{abstract}
Engagement in an online activity is hard to sustain. Online engagement comprises a wide range of domains, and substantial classifications change in accordance with context and desired objectives (Looyestyn et al., 2017). The concept of engagement is obvious and involves cognitive and emotional concentration that may not describe all social media utilization (Smith \& Gallicano, 2015). Engagement has appeared as an important idea for news agencies. Thus, this study explained media engagement, to know the extent of client experiences via web-based media, propagate engagement designs and experiences. Our research comprises of quantitative and qualitative approaches to describe the web-based engagement as a set of experience. It describes, engagement can be explained in two significant forms (those are, individual engagement and public-collaborative engagement) for advertising firms and show their expected legitimacy by demonstration that these two are connected via readership.
\end{abstract}

Keywords: viewers; engagement; experience; readership

Reference to this paper should be made as follows: Rungsrisawat, S., Chankoson, T. 2020. Engagement with online media, Journal of Security and Sustainability Issues, 9(4), 1379-1391. http://doi.org/10.9770/jssi.2020.9.4(22)

\section{Introduction: media engagement and experiences}

Digitalization changes daily lives. There is a lot of attention to positive and negative effects of on-line activities (Štefko, Bačík, Fedorko, Oleárová, Rigelský, 2019; Pogodina, Aleksakhina, Burenin, Polianova, Yunusov, 2019; Vlasov, Shakhnov, Filin, Krivoshein, 2019; Vasilev, Gapsalamov, Akhmetshin, Bochkareva, Yumashev, Anisimova, 2020; Tesařová, Krmela, Šimberová, 2020; Andriushchenko, Buriachenko, Rozhko, Lavruk, Skok, Hlushchenko, Muzychka, Slavina, Buchynska, Kondarevych, 2020; Buchynska, Kondarevych, 2020; Plèta, Tvaronavičienè, Della Casa, 2020).In past years, the newspaper industry undergoes important loss of revenues, mainly in print advertising. The increased interest in the online marketing has been unable to fulfill this loss (Sridhar, S., \& Sriram, S. (2015). Mass media (like TV, newspaper, radio, and the internet) can effectively modify our values, way of life, and also it is capable of directing viewer interest and trends (Jermsittiparsert, Sriyakul, \& Pamornmast, 2013; Kejriwal \& Chakravorty, 2014). As described by (Bangkokpost), Digital advertisement in Thailand for the year 2019 should reach 124 billion baht (baht is Thailand's official currency) making growth of $4.8 \%$. In Thailand, web networking is a basic provider of internet marketing, responsible for $14.5 \%$ out of total 124-billion-baht ad market. The major difference among online advertising and print advertising is scope of advertisement. Internet based advertising can reach consumer worldwide. This reveals that online advertising can effectively reach a greater number of consumers at any place and allow small businesses to grow far outside the local area. Most of journalist experts and scholars have recently discussed that newsroom adopt viewers engagement as one of their major interest (Nelson, J. L. (2018). During the past few decades, with the emergence of online advertisement the newspaper circulation and print advertisement fell underneath. Newsrooms were discussing about the suitable ways to develop and retain readership, and advertisers 
are considering the possibility to monetize the readership. These concerns are important in view of journalism, and we consider these concerns as the questions of engagement. For this research, engagement can be described as the common experiences about viewer's via media brand. Experience is firmly related to the learning concept because experience can be considered as the origin of knowledge that is taught (Barron et al., (2015). In this study, we describe that how a brand enables users to have different experiences. It has been investigated that understanding develop by a firm is the primary move to create and manage a top media brand (i.e. TV programs, Internet sites, newspapers, magazine). To understand the fact that engagement and experiences facilitate firms of journalism to develop and facilitate such worth to clients and separate their contributions from other individuals. Thus, an idea behind this study is to explain engagement, to know the extent of client experiences via web-based media, propagate engagement designs and experiences, and evaluate the expected verification of our measures. Newspapers provide instant news, and effect readers' perception of the era in which they lived and support to configure historical memory (Heyd, U. (2017). To know about the fact that how an individual can be involved in some publication, we should start knowing the way in which media brands (i.e. TV programs, Internet sites, newspapers, magazine) set into its reader's routine. This assumption modifies the task of explaining engagement complicated because the relationship among publication and its readers are difficult as well as complicated. Focus on a media brand that circulates content through print publication and internet website. Obviously, readers might be involved with publication for the reasons they think that it attaches them to the group they have a good time interacting via conversations. In addition, they feel connected to it because it facilitates refining of all published updates that is end- users needs to sustain with some content and trust that this print publication will facilitate them with the content they required to know. On the other side, readers might see reading the newspaper as an approach to calm down and relax after a hectic routine of a day. This can also be a reason for their engagement that it makes them appealing by facilitating with new topics for discussion. Study on engagement has mainly focused on explaining the engagement nature and its scope (Baldus et al., 2015). The main idea basically is that engagement of individuals with any media brand provides them a way to make experiences through that product or item. The media brand exhibits significant role in individual's life. Individuals are having timeout experience when they read publication just to calm down and for their relaxation. People who engaged in reading publication for things to discuss are having experience called as public-facilitation experience. Usually, a collection of ideas and views about the possibility of publication involvement in an individual life routine is known as engagement. Whereas, engagement can be defined as a high quality, integrated emotion of reader, which could not be calculated instantly, readers aware with the existence of involvement through ideas and views, which are easily measurable. The empirical section of our study will consider further experiences and, also contain the way in which calculation cab be carried out as latent variables utilizing element assessment. Individual thoughts about some publication like 'this newsprint facilitate me relaxation; and 'I prefer to chill down and wind down this newsprint' will turn into survey questions that carried on a $\left(1^{\text {st }}\right.$ order $)$ public facilitation experience component. Now, our study demonstrates that a set of experiences that readers adopt with a media can be called as engagement (see Fig 1). On the other hand, experience can be defined as the ideas and views the reader own about how it sets into its routine life. According to this evaluation, several media requirements do not provide the similar experiences for interest development. Few might be interested due to the reason that they facilitate increase levels of utilitarian experience, delivering beneficial suggestions and guidance, while other may be interested because they are substantially pleasing. Experiences are not particular all the time, and some content might produce higher level of compound experiences. Essentially, it has to be understood that there are multiple paths of involvement and those different paths are figure out by consideration of variety of experiences, which allow the brand to discriminate itself from others. Such as, the transportation part of Thai Rath newspaper. Few articles engaged peoples by describing utilitarian experience, where the people think that the article providing beneficial suggestions. Some articles are engaging people because they enjoy intrinsic pleasure. 


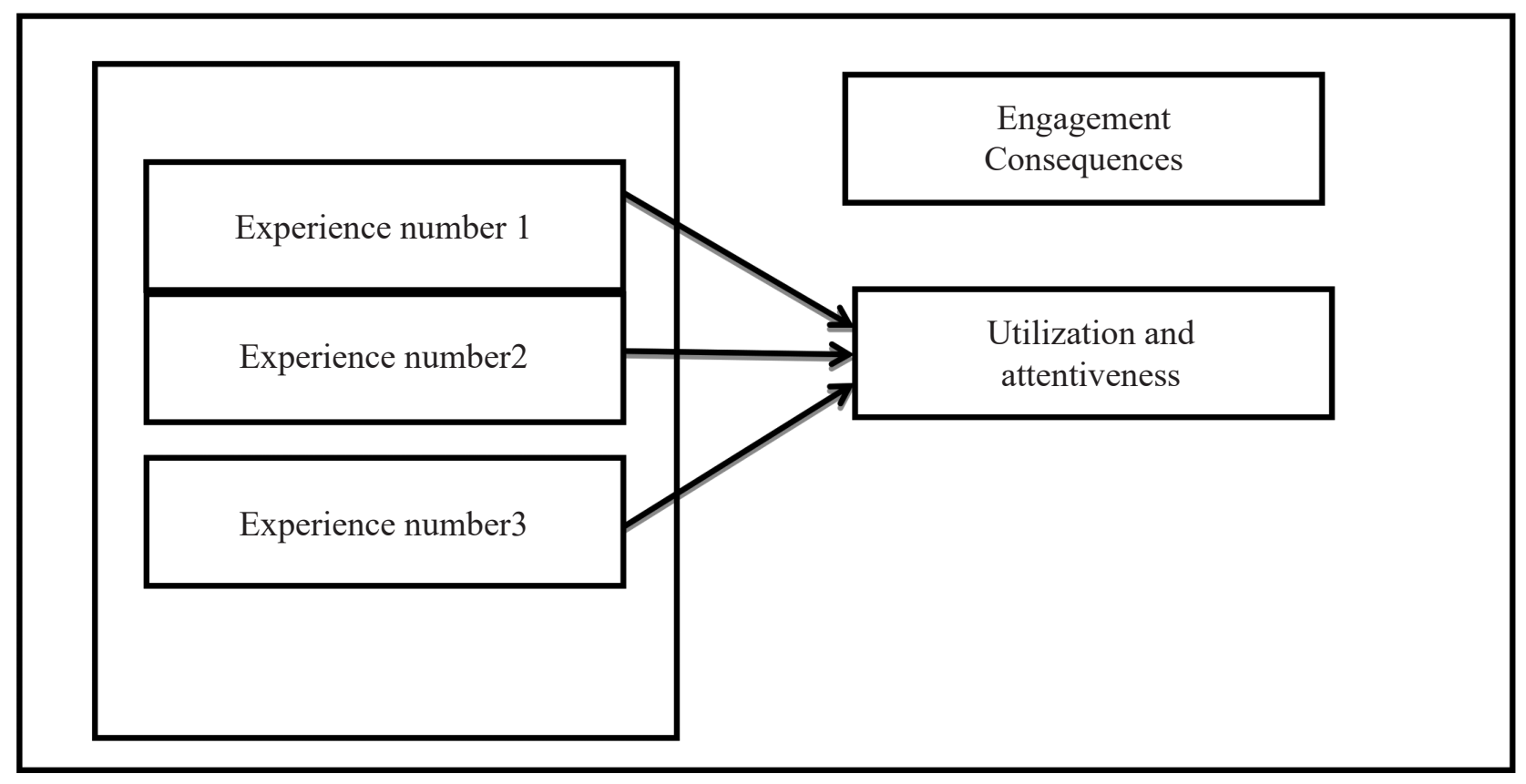

Fig 1. Experiences, Engagement and their consequences

So, we evaluate that the high level of readership provided directly by readers experiences that lead to engagement. As shown in figure 1, we thus hypothesized

H1: Engagement and readership are connected with each other positively.

For developing calculations of engagement which we defined before, we are required to construct a sample of experiences through structural scope, but before sampling, first we have to develop the limitation of this scope. For this, we consider uses and gratification context, which earlier utilized by mass media investigators to recommend that people tells their requirements and commands regarding media searching procedure in order to gratify those requirements.

Uses and Gratification theory that explain several types of media uses selected by different peoples and basically consider for the measuring individual engagement in any media. According to (Rubin, 2009), Uses and Gratification Theory emerged from theories concerning why individuals select various kinds of media assumption. Also it has been utilize to analyze client engagement in web based networking sites (Ku et al., 2013); (Whiting, A., \& Williams, D. 2013) video sharing (Chiang, H. S., \& Hsiao, K. L. 2015), live streaming (Sjoblom, M., \& Hamari, J. (2017), and eSports (Sjoblom, M., \& Hamari, J. 2017). In accordance with U\&G theory, people actively searching, spend, and involve in media that meet their personal requirements and match their priority better than other media choices. U\&G theory presents practical approach which facilitates the understanding process of how several forms of media engagement related to the satisfaction of several psychological needs (Hilvert et al., 2018). Therefore, U\&G theory supports a structure for understanding client preferences and role in media engagement as practices which are responsible for satisfaction of person's psychological needs. Uses and Gratification theory creates a history of communication theories and research. It starts by researchers' study of radio listeners. Uses and Gratification theory reinforce by Katz, Hass and Gurvitch in 1973 and it was proposed in 1940s, is designed to determine psychological needs that encourage the utilization of any particular medium to gratify those needs. According to U\&G theory peoples utilizes media strategically (Merhi, M. I. 2016).In accordance with Uses and Gratification theory, peoples are active in assessing any convenient media and will make wise choices to select the medium they think will better fulfill their requirements and optimize their personal gratification. Whereas Uses and Gratification theory assumes that peoples understand their personal needs, it is implies to figure out that why peoples select one particular medium instead of other medium based on the previous media's advantage (Luo, M. M., \& Remus, W. 2014). 
(McQuail 1983) proposed Gratification theory and suggested four utilizations of media:

- Information: searching for suggestions and recommendations on practical matters or decision preferences; fulfill concerns, curiosity and common interest and attaining feeling of protection through knowledge.

- Personal Identity: seeking out support for personal interests; attaining insight awareness of own self.

- Integration and social interaction: interacting with others and attaining a sense of communicated; make individual capable to coordinate with family, friends, peers and society.

- Entertainment: relaxing, running away, or being away from concerns, issues and difficulties.

Web based gratification theory is different in several ways than those of conventional published products. These differences enhanced by interactivity concept explained by (Ruggiero, T. E. 2000). The actual benefit of interactivity for person is not only about multimedia videos, buying online, or gaining knowledge on demand, interactivity facilitate individual the way to create new means of communication. Also, interactivity substantially enhances the core uses and gratification concept of active user.

We followed McQuail's typology and Ruggiero recommendations about further interactivity elements, as the construct scope, and we named those elements as extended uses and gratification context. The various roles prescribed using this context are experiences. In measurement model terminology, experiences are top-order construct whereas $2^{\text {nd }}$ - order construct refer to engagement. So, when we will point to a particular collection of client beliefs regarding vehicle, we will refer the term as experience, and when we will point to an entire experience regarding vehicle, we will refer the term as engagement. Thus, the purpose of our study is to evaluate the several experiences within the extended uses and gratification context element. Our description regarding engagement as a set of experiences comprises several explanations that has now been enhanced. Like an aspect of engagement by (Pantic, M. 2017) is active user, in the today's media atmosphere, they actively select whatever they want to utilize from a broader variety of content than ever before, and normally engaged in a news generation process. (Munson et al. 2015) explains, to increase engagement, practical application adopts gamified features because health gamification may assist behavior modification. (Krebs, I., \& Lischka, J. A. 2019) focused on comment reading; Comment reading may facilitate readers with more knowledge to form opinions. Another aspect is, digital editor of Telegraph Media Group (TMG) Edward Roussel has focused on action. Roussel, E. (2008). Defines, publishing newspaper to develop capability (internet based) that promote user to give eyewitness reports about newsflash, give reviews about services, and get into arguments. The contribution approximations also enhanced by Mr. Jaranpisit Changpunt, vice president of The Nation and Ms. Worarak Ingkamanee, senior vice president of The Nation(The Nation is daily digital newspaper of Thailand, published in Bangkok). Samorn Terdthampiboon, president of Thai post (Thai post is a daily newspaper published in Bangkok in Thai language). We named this as participatory and socializing experience. Further more broadly utilized by reporters and journalism researchers are a substitute approach to engagement in society involvement or participation terminology (Mersey, R. D. 2009a): (Mersey, R. D. 2009b)). We will name it as civic experience. This point of view brought in front by (Putnam, R. D. 2000), awards concerns to the communication peoples having with each other and their geographical societies. Putnam's considerations usually focused by investigators of conventional publications, but this native structure has also been utilized by scholars of web media. The 'participatory and socializing' and 'civic experience' both definite means about engagement, so, we refer them as demonstrating of a second-order engagement construct. However, uses and gratification researchers famous for long time, because of several other utilitarian, hedonic and public intellectual objectives. Our approaches to be engaged as a $2^{\text {nd }}$ order construct provide assessments and facilitate further ways to be engaged.

\section{Method and Outcomes}

Our approach includes many steps, which we will discuss in detail further.

\section{Selecting Experience Scales}

First of all, we had to choose estimation scales for a collection of web-based experiences, which grabs uses and gratification framework elements and are engagement indicators. Theoretically these proportions must result in 
appropriate fit in an estimation model and possess suitable psychometric characteristics for example appropriate reliability.

We utilized collection of mass media experiences Calder-Malthouse (CM), the reason that they facilitate estimation with respect to wide spectrum of experiences (Calder, B. J., and Malthouse, E. C. 2004); (Calder, B. J. and Malthouse, E. C. 2005); (Malthouse et all 2007)). We sum up the Calder-Malthouse approach and discuss that these experiences extent the scope of engagement. Calder-Malthouse continues 350 hours, interviews with clients about the task that particular internet site, magazine, newspaper and Television news telecast perform in those individual's daily routine. They evaluate the transcripts for regular aspects and create numbers of measuring components. These components were added in a media user's survey. Exploratory items evaluation determined 20 web-based experiences, 42 print publication experiences, 36 magazine experiences and 11 Television news experiences. The coefficient alpha values recommend that many scales were reliable (with few having weak reliability due to very small number of items). Actual CM studies do not estimate confirmatory elements analysis (CFA) models.

For confirmatory evaluations, we selected eight experiences from the total of twenty experiences, because of constraint survey range and respondent fatigue. In examining the actual 20 experiences, we conclude that few are not appropriate for construct domain for the reason that they explain the website itself instead of describing how the website fits into client's routine life, such as take an example of the experience; it was regarding reliability of the website. Many experiences were abandoned because they were particularly about the publication on the websites (Thaker et al., 2020).

In Table 1, we present eight experiences along with their items. We have choose with the stratifying sampling process through the rest of the experiences in order to utilize from the four McQuail's uses and gratification classification that identify more conventional means of communication, and further, for example 'society' and 'participatory and socialization' which are specifically related to means of communication via internet. We try not to take too much experience for McQuail uses and gratification classification, such as; three experiences among the leftover experiences go according to McQuail's classification named as 'information': "want to be informed," it is regarding making individuals updated on matters that concern them, and "utilitarian," it is regarding suggestions. After tossed, we selected to add utilitarian. Similarly, the actual Calder-Malthouse experiences "native pleasure," and "amuse and engross me", these two experiences go according to McQuail's enjoyment classification and we choose the first one randomly. The "public facilitation" fit under a McQuail's integration and interaction category, so we selected this for this classification. The "self-assessment and civic spirit" go with McQuail's personal identity classification.

Table 1. questionaries' wordings and Parameter Estimation with CFA Measurement Model

\begin{tabular}{|c|c|c|}
\hline Experience & Component & Stand Loading \\
\hline \multirow{5}{*}{$\begin{array}{c}\text { Encouragement and } \\
\text { motivation } \\
(\alpha=0.88)\end{array}$} & This website facilitates my personal life through inspiration. & 0.84 \\
\hline & this website drives me to see things in new possibilities & 0.85 \\
\hline & This website promotes my thinking about several different matters. & 0.79 \\
\hline & I feel myself more interesting because of this website. & 0.78 \\
\hline & Some of this website stories strongly touched me. & 0.72 \\
\hline \multirow{3}{*}{$\begin{array}{l}\text { public facilitation } \\
\qquad(\alpha=0.88)\end{array}$} & I elevate things which I have seen while interacting with several other individuals. & 0.84 \\
\hline & this website usually facilitate me something new to discuss & 0.83 \\
\hline & I utilize things through this website in debating or communicating people I know & 0.85 \\
\hline \multirow{4}{*}{$\begin{array}{l}\text { Temporal } \\
(\alpha=0.90)\end{array}$} & This belongs to my daily routine life. & 0.84 \\
\hline & Whenever I surfing the internet I go to this website & 0.85 \\
\hline & I see this website as an essential part of receiving the news for the day & 0.83 \\
\hline & This website encourages me to start a day in the morning. & 0.81 \\
\hline
\end{tabular}




\begin{tabular}{|c|c|c|}
\hline \multirow{5}{*}{$\begin{array}{l}\text { Self- assessment \& } \\
\text { civic-spirit } \\
(\alpha=0.91)\end{array}$} & I feel myself better citizen through using this website. & 0.85 \\
\hline & This website makes difference in my daily routine life. & 0.86 \\
\hline & This website mirrors my values. & 0.75 \\
\hline & This website increase my participation in society & 0.76 \\
\hline & Through this website I feel myself as a better person & 0.87 \\
\hline \multirow{5}{*}{$\begin{array}{l}\text { Native pleasure } \\
\qquad(\alpha=0.87)\end{array}$} & This website is a treat for me & 0.82 \\
\hline & Spending time on this website alters my mood and makes me feel happy & 0.84 \\
\hline & I want to kick down and calm down with this website & 0.81 \\
\hline & I prefer to see this website while I am relaxing or eat something & 0.66 \\
\hline & I never think of other website while I am using this website & 0.70 \\
\hline \multirow{5}{*}{$\begin{array}{l}\text { Utilitarian } \\
(\alpha=0.88)\end{array}$} & This website support me in making buying decisions & 0.83 \\
\hline & This website support the learning about making yourself a better person & 0.81 \\
\hline & It enables me in making important decision by providing information & 0.77 \\
\hline & This website helps me in managing by money & 0.80 \\
\hline & $\begin{array}{l}\text { I give suggestions and advices to other users I know based on the thing } \\
\text { I came to know from this website }\end{array}$ & 0.75 \\
\hline \multirow{4}{*}{$\begin{array}{l}\text { Participatory \& } \\
\text { socialization } \\
(\alpha=0.88)\end{array}$} & I will lower socialization on this website & 0.85 \\
\hline & I participate to the discussion on this website & 0.76 \\
\hline & I usually guilty regarding the socializing time I have spent on this website & 0.81 \\
\hline & I should possibly chop off the socializing time I spent on this website & 0.77 \\
\hline \multirow[t]{6}{*}{$\begin{array}{l}\text { Society } \\
(\alpha=0.88)\end{array}$} & I am interested in users review as I am the regular content on this website & 0.85 \\
\hline & The basic reason of liking his website is what I get from other peoples & 0.84 \\
\hline & This website facilitate its visitors in a better way to provide reviews & 0.60 \\
\hline & I am interested to meet other users who are regular visitors of the website & 0.81 \\
\hline & $\begin{array}{c}\text { because of this website } \mathrm{i} \text { am now interested in those things } \\
\text { otherwise would not have }\end{array}$ & 0.72 \\
\hline & $\begin{array}{l}\text { Generally, the users on this website are well aware bout the topics } \\
\text { it defines so they can be advantageous for you }\end{array}$ & 0.67 \\
\hline
\end{tabular}

The above eight experiences represent engagement construct domain. Obviously, further sets can also fit under our scope, but our approximation is completely constant with our motive of creating engagement clues.

\section{Survey Methodology}

The second step is sampling media websites users. 11 internet sites regarding mass communication were utilized in the current evaluation of confirmatory. These websites present a relevant sampling but added wide range of several kinds of sites regarding mass communication including sites having national level fame (such as bangkokpost.com), special interest websites (such as thaipost.net). The targeted public, determined by screening questionnaires, was individuals who visit the website at least once in a month. Individuals were drafted from the specific website visitors, who were redirected to a survey on internet. The sampling range for the eleven websites are from $n=36$ to $n=1290$. Participants were inquired about their experiences and usage about specific website.

\section{Measurement Models for Experiences and Engagement}

The further move was about creating online engagement measures as follows:

(a) Evaluate a CFA measurement model to evaluate psychometric characteristics of measures of our experience.

(b) Utilizing eight experiences, we create second order engagement elements through the application of exploratory element analysis.

(c) Fits second order Confirmatory element analysis (CFA).

We assess and try every available pair of experiences to be associated. Table 2 represents fit statistics. Table 
1 contains the values of coefficient alpha, questionaries' wordings, and element loadings. There were total 37 items utilized to calculate eight experiences. The result showed that, every single scale from eight scales is extremely credible, along with coefficient alpha range 0.88 to 0.93 . CFI, GFI, and NNFI all reached to 0.90 , specifying a suitable fit. Discriminant and convergent legitimacy were suitable.

Table 2. Summarizing CFA Model

\begin{tabular}{|c|c|c|}
\hline & Measurement & Second order \\
\hline Parameters & 103 & 88 \\
\hline CFI & .9156 & .9030 \\
\hline GFI & .9481 & .9391 \\
\hline NNFI & .9427 & .9345 \\
\hline RMSEA & .0471 & .0404 \\
\hline $\mathrm{n}^{1}=5941$ having 37 items & \multicolumn{2}{|}{} \\
\hline
\end{tabular}

Table 3 represents the Individual association among the experiences and a pattern which was followed indicates the possibility of $2^{\text {nd }}$ order elements. The first 6 experiences are slightly associated with each other, with value range .41 to .74 . Participatory and socialization experience is considerably less associated with the other 6 experiences, but slightly associated to society experience. Society is less associated to first 6 experiences. This association configuration recommends that there is a first-order elements configuration producing the figures.

Table 3. Association hierarchy

\begin{tabular}{|c|c|c|c|c|c|c|c|c|c|c|}
\hline \multicolumn{10}{|c|}{ Individual Association } & \multirow[b]{2}{*}{ ten } \\
\hline Experience & one & two & three & four & five & Six & seven & eight & nine & \\
\hline \multicolumn{11}{|l|}{ Encouragement and motivation } \\
\hline Public facilitation & 0.52 & & & & & & & & & \\
\hline temporal & 0.52 & 0.54 & & & & & & & & \\
\hline Self-assessment \& civic spirit & 0.66 & 0.56 & 0.48 & & & & & & & \\
\hline Native pleasure & 0.65 & 0.52 & 0.63 & 0.64 & & & & & & \\
\hline Utilitarian & 0.61 & 0.52 & 0.42 & 0.71 & 0.56 & & & & & \\
\hline Participatory and socialization & 0.25 & 0.18 & 0.18 & 0.30 & 0.32 & 0.36 & & & & \\
\hline Society & 0.47 & 0.42 & 0.32 & 0.54 & 0.53 & 0.56 & 0.56 & & & \\
\hline \multicolumn{11}{|l|}{ Engagement } \\
\hline Individual engagement & 0.82 & 0.76 & 0.76 & 0.84 & 0.82 & 0.75 & 0.33 & 0.59 & & \\
\hline Interactive engagement & 0.57 & 0.48 & 0.42 & 0.70 & 0.66 & 0.75 & 0.76 & 0.91 & 0.74 & \\
\hline \multicolumn{11}{|l|}{ Readership } \\
\hline & 0.28 & 0.26 & 0.47 & 0.23 & 0.22 & 0.33 & 0.14 & 0.24 & 0.38 & 0.28 \\
\hline
\end{tabular}

Thus, the next step in creating the measurement model is to determine the second-order engagement element utilizing both exploratory and CFA. We carried out exploratory element evaluation with a varimax rotation on the first-order experiences and found two eigenvalues greater than one. Table 4 represents rotated element loadings and presents two interpretable elements, from now on called an individual engagement and publiccollaborative engagement. Associated hierarchy of first six experiences has the biggest loadings on individual engagement, even though society also contain cross-loading element larger than three. 'Society' and 'Participating and socialization', these two exhibiting biggest loadings on public-collaborative engagement; with many other experiences have substantial cross-loadings. The utilitarian experience possibly cross-loadings on public-collaborative engagement due to the fact that most of the suggestions and recommendations might be provided through user's society instead of through the content produce by workforce of the website itself. Selfassessment possibly cross-loading due to the reason that contribution to a web-based discussion contributes to individual self-assessment. 
Table 4. Exploratory Element Calculation Loadings of First-Order Experiences

\begin{tabular}{|c|c|c|}
\hline Experience & Element 1: individual engagement & Element 2: collaborative engagement \\
\hline Public facilitation & .769 & \\
\hline Temporal & .752 & .374 \\
\hline Encouragement and motivation & .745 & .365 \\
\hline Self-assessment and civic spirit & .712 & .471 \\
\hline Native pleasure & .702 & .882 \\
\hline Utilitarian & .613 & .754 \\
\hline Participatory and socialization & & \\
\hline Society & .362 & \\
\hline
\end{tabular}

Further we calculate a $2^{\text {nd }}$ order CFA to examine if there might be any possibility that the individual and public collaborative engagement latent variables produce the respected association construct among the item and experiences. Public-collaborative and individual engagement would be utilized in the further evaluation regarding readership. Table 2 represents appropriate credentials, with GFI, CFI, and NNFI all greater than .9 representing suitable figures. Parameter estimation of second-order element represent in Fig 2

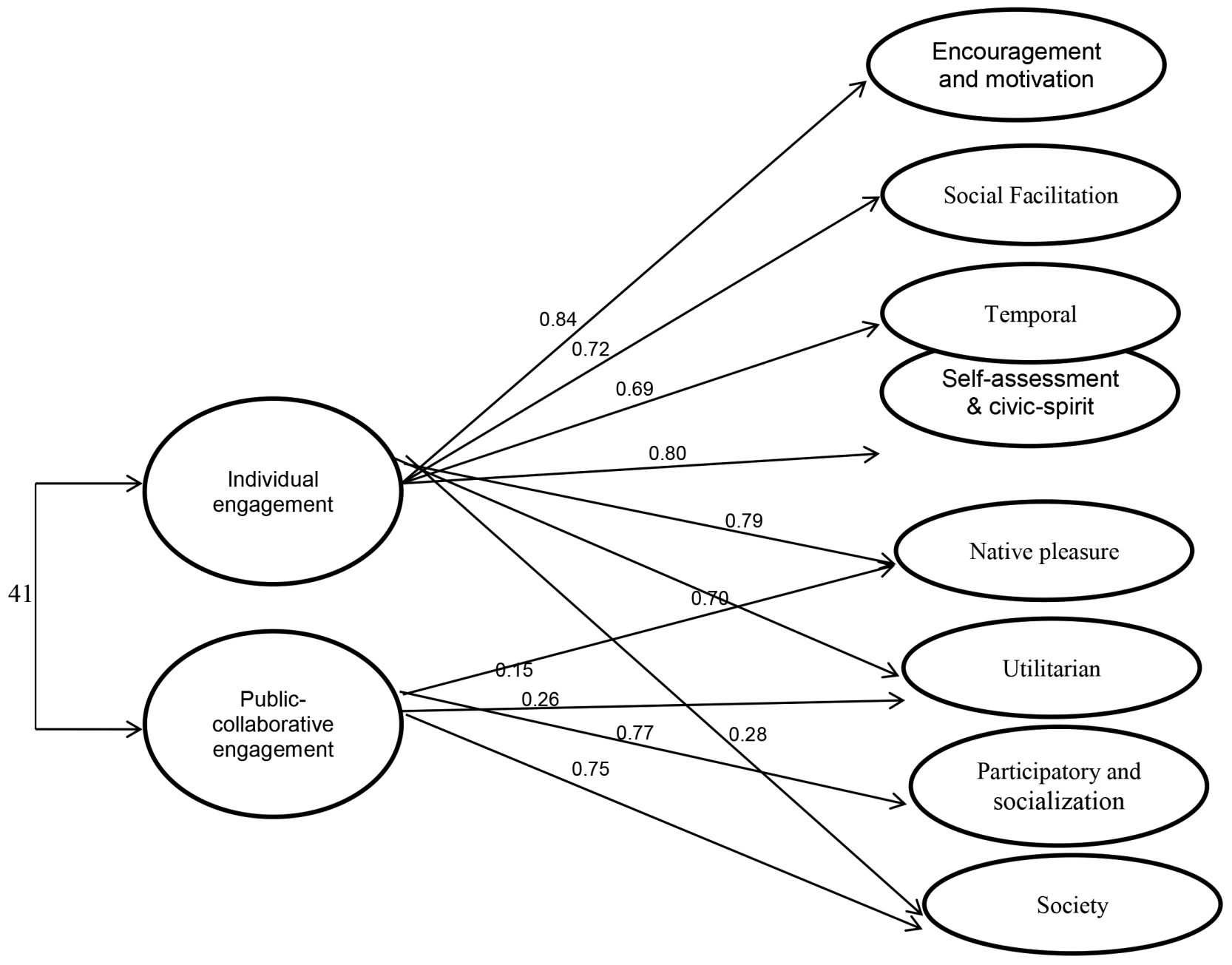

Fig 2. Order Engagement Element Construct 
Individual engagement is demonstrated in experiences that are in accordance with the experiences that people have with magazine and printed newspaper. Such as, item of experience for example "this website drives me to see things in new possibilities" or "this website usually facilitates me something new to discuss" might also be applicable to print. Public-collaborative engagement, somehow, is highly particular to websites. Components for example "I will lower socialization with this website" and "I participate through discussion on this website" couldn't describe print. On the other hand, public-collaborative engagement is much nearly correlated to internet, features of it can be considered for some other means of communication. The utilitarian experience is exhibiting both forms of engagement.

Thus, it has been seen through the estimation and values of coefficient alpha that eight experiences were calculated with high reliability and the competent and determinant legitimacy of scales were also supported. The $2^{\text {nd }}$-order evaluation presents two elements of engagement, public-collaborative and individual engagement. Individual engagement is demonstrated by the experiences that have been carried out in printed publications (such as magazines and newspapers), whereas public-collaborative engagement is mainly précised to internet websites. Fig 2 represents the loadings, users having individual engagement searching out for motivation and encouragement from the website; they need to utilize the internet site to utilize their contacts with more individuals, users get a feeling of native pleasure in utilizing the website, they seems it beneficial for achieving targets, and users appreciate contribution from other peoples. Users of public-collaborative engagement experiences some of the similar things in a way of native pleasure, utilitarian worth, appreciating the contribution through bigger user's communities but in a manner that relate to a feeling of involvement with other peoples and socialization on the internet sites. Therefore, public-collaborative engagement is stimulated both intrinsically and extrinsically. Further it is the appreciation of contribution from the participants of society and idea of involvement with more people and socialization that provide public-collaborative engagement as its leading status.

\section{Engagement Validity}

Now, we examine our expected measurements validation by evaluating if engagement is related with readership. We calculate readership through SUM (Site Usage Measure) and associate it through utilizing two methods for both engagement types. SUM refers to the standard number of website visits and the total duration on a website. First of all, Table 3 represents positive and very important association with readership from individual and public-collaborative engagement. Increased readership's level is related to increased engagement level of some other type. Simple association, whereas, have many limitations, which would be considered in next evaluation study:

(a) They do not allow for unlike associations for different websites.

(b)They do not report for the association among both engagements' types.

The further evaluation utilizes two apart hierarchical models (HLM) to anticipate RBS from two kinds of engagement (see Table 5), for engagement at website level we added a random intercept and random slopes. The slope for individual engagement as well as public-collaborative engagement is productive and very important. No single random effect is important which specifying that we do not have any proof to state that the relationship fluctuate among different websites. We thus recommend that our engagement measurements forecast readership.

Table 5. Engagement with a HLM

\begin{tabular}{|c|c|c|c|c|c|c|}
\hline & \multicolumn{3}{|c|}{ Fixed effect } & \multicolumn{3}{c|}{ Random effect } \\
\hline Effect & slope & Standard error & p-value & deviation & Standard error & p-value \\
\hline Intercept & 0.6393 & 0.08086 & $<0.0001$ & 0.006809 & 0.01017 & 0.2419 \\
\hline Personal & 0.7377 & 0.02474 & $<0.0001$ & 0.000559 & 0.000979 & 0.2844 \\
\hline Intercept & 1.5589 & 0.08096 & $<0.0001$ & 0.01433 & 0.007956 & 0.0360 \\
\hline interactive & 0.5503 & 0.02654 & $<0.0001$ & 0 & & \\
\hline
\end{tabular}




\section{Results and Managerial Implications}

With this study we evaluated three contributions:

(a) Engagement refers as a set of experiences.

(b) We showed engagement types which are individual engagement and public-collaborative engagement.

(c) Manifest that two engagement types contain forecasted validation due to the reason that they are related with readership.

These outcomes promote uses and gratification construct, earlier described, by developing those experiences that provide engagement beneficial for the growth of readership. Now, it is logical to declare that mass communication related firms 'arguing about the way to create and retain readership' must concentrate on experiences creation to facilitate readers associated to the $2^{\text {nd }}$-order construct related to individual engagement. Experiences and engagements have several important managerial implications. We suggest an approximation (Fig. 3) to make a media brand (Calder, B. J. and E. C. Malthouse (2008a); (Calder, B. J. and E. C. Malthouse 2008b). The media firm must express an idea that will direct its formation of connections to facilitate media brand. (Calder, B. J. 2010) examines the way of merging a collection of experiences and proposed a conception allocation declaration. Experiences are produced by contacts for the viewers and in this way relate to the concept. Editorial and commercial content and its presentation can be added by contacts by their selves, also the publications and happenings about the media brand. The viewer's thoughts regarding concept build hopes, which could also influence their experiences with brand, including their activities beyond it.

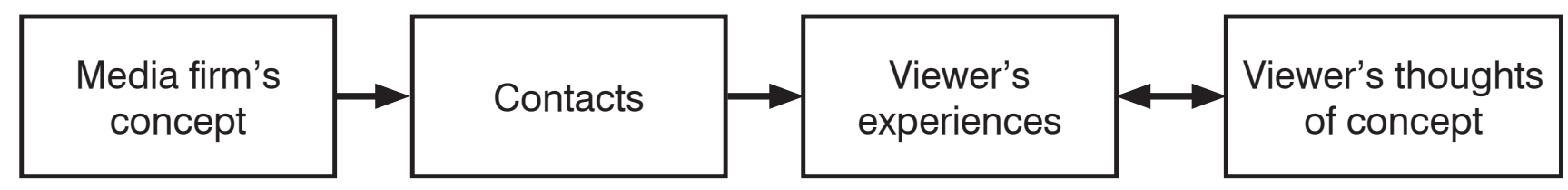

Fig 3. A Procedure for developing Experiences

Periodically, media firm must utilize the scale suggested in this research estimation if the viewers are owning experiences determined in the declarations for many different causes.

(1) These estimations can facilitate an earlier caution that the intended experiences are not being formed.

(2) These evaluated estimations are beneficial to marketers, who are seeking for media-neural metrics regarding common-currency comparison reason.

(3) Engagement can be used by media managers as a possibility to distinguish from their opponents and retain marketers.

Actual debate is readers those are having increased engagement level much better exposed to advertisements; advertise conveyed by vehicle through increased readers engagement must control a premium price for ad space, or at least take a benefit in retaining marketers.

\section{Conclusion}

In this research we have investigated that experiences and engagement supports organization to create and retain client value and considering their worth by separating it from other peoples. It has been concluded that engagement has two types; comprises of many different experiences and that every experience has its own uniqueness. Media utilization normally exhibits a productive relation with engagement along with its two more categories. This paper describes a qualitative research on U\&G which enhances the uses and gratification theory. This study explicates a media role supports engagement behaviors under the media domain. We have indicated that strong readership possesses strong engagement, and the two subcategories of engagement are related through the readership domain. We have seen that the media (i.e. TV programs, Internet sites, and newspapers, magazine) impacts on an individual measure of engagement, which contribute to individual's life with several experiences. An individual with strong engagement and experiences lead the company to develop and maintains a successful 
media brand. So, the basic concept is that, user's engagement with any specific brand facilitates a means for creating experiences via brand product. This study provides a several contributions to journalism firms and offers hypothetical implementations. The current paper responds to calls about the empirical requirements for evaluating the individual engagement and involvement. Further studies might be seeking a way to more evaluate readership and user engagement.

\section{References}

Andriushchenko, K., Buriachenko, A., Rozhko, O., Lavruk, O., Skok, P., Hlushchenko, Y., Muzychka, Y., Slavina, N., Buchynska, O., Kondarevych, V. (2020). Peculiarities of sustainable development of enterprises in the context of digital transformation. Entrepreneurship and Sustainability Issues, 7(3), 2255-2270. http://doi.org/10.9770/jesi.2020.7.3(53)

Baldus, B.J., Voorhees, C., Calantone, R (2015).: Online brand society engagement: scale development and validation. J. Bus. Res. 68, 978-985. https://doi.org/10.1016/j.jbusres.2014.09.035

Bangkokpost https://www.bangkokpost.com/business/1611822/thailands-digital-advertising-poised-for-growth

Barron, A. B., Hebets, E. A., Cleland, T. A., Fitzpatrick, C. L., Hauber, M. E., \& Stevens, J. R. (2015). Embracing multiple definitions of learning. Trends in neurosciences, 38(7), 405-407. https://doi.org/10.1016/j.tins.2015.04.008

Calder, B. J. (2010). Media concepts. In A. Peck \& E. C. Malthouse (Eds.), Medill on Media Engagement. New York: Hampton Press.

Calder, B. J. and E. C. Malthouse (2008a). Media Engagement and Advertising Effectiveness. In B. J. Calder (Ed.), Kellogg on Media and Advertising (1-36). New York: Wiley.

Calder, B. J. and E. C. Malthouse (2008b). Media Brands and Integrated Marketing. In M.Ots (Ed.), Media Brands and Branding. Media Management and Transformation Centre, JIBS Reseach Report No. 2008-1, 89-94.

Calder, B. J. and Malthouse, E. C. (2005), Experiential Engagement with Online Content Web Sites and the Impact of Cross-Media Usage, Proceedings of 12th Worldwide Readership Research Symposium, Prague, October.

Calder, B. J., and Malthouse, E. C. (2004). Qualitative media measures: Newspaper experiences. The International Journal on Media Management, 6 (1/2), 124-131. https://doi.org/10.1080/14241277.2004.9669388

Chiang, H. S., \& Hsiao, K. L. (2015). YouTube stickiness: The needs, personal, and environmental perspective. Internet Research, 25, 85e106. https://doi.org/10.1108/IntR-11-2013-0236

Heyd, U. (2017). Reading newspapers.

Hilvert-Bruce, Z., Neill, J. T., Sjöblom, M., \& Hamari, J. (2018). Social motivations of live-streaming viewer engagement on Twitch. Computers in Human Behavior, 84, 58-67. https://doi.org/10.1016/j.chb.2018.02.013

Jermsittiparsert, K, Sriyakul, T., \& Pamornmast, C. (2013). Quality of Thai Media: Empirical Proposals on "Prime Minister's Eggs" Discourse. Asian Social Science, 9(17), 209-217. https://dx.doi.org/10.5539/ass.v9n17p218

Katz, E., Haas, H., \& Gurevitch, M. (1973). On the use of the mass media for important things. American Sociological Review, 38 (2), 164-181. https://psycnet.apa.org/doi/10.2307/2094393

Kejriwal, R., \& Chakravorty, D. K. (2014). Impact of Income on Media Selection by FMCG Consumers: A Study on Kolkata. The International Journal of Business \& Management, 2(5), 193-200.

Krebs, I., \& Lischka, J. A. (2019). Is audience engagement worth the buzz? The value of audience engagement, comment reading, and content for online news brands. Journalism, 20(6), 714-732. https://doi.org/10.1177\%2F1464884916689277

Ku, Y. C., Chen, R., \& Zhang, H. (2013). Why do users continue using social networking sites? An exploratory study of members in the United States and Taiwan. Information \& Management, 50, 571e581. https://doi.org/10.1016/j.im./2013.07.011

Looyestyn, J., Kernot, J., Boshoff, K., Ryan, J., Edney, S., \& Maher, C. (2017). Does gamification increase engagement with online programs? A systematic review. PloS one, 12(3), e0173403. https://doi.org/10.1371/journal.pone.0173403

Luo, M. M., \& Remus, W. (2014). Uses and gratifications and acceptance of Web-based information services: An integrated model. Computers in Human Behavior, 38, 281-295. https://doi.org/10.1016/j.chb.2014.05.042 
Malthouse, E. C., Calder, B. J., \& Tamhane, A. (2007). The effect of media context experiences on advertising effectiveness. Journal of Advertising, 36 (3), 7-18. https://doi.org/10.2753/JOA0091-3367360301

McQuail, D. (1983). Mass communication theory: An introduction. London: Sage Publications.

Merhi, M. I. (2016). Towards a framework for online game adoption. Computers in Human Behavior, 60, 253-263. https://doi. org/10.1016/j.chb.2016.02.072

Mersey, R. D. (2009a). Sense of Society Differs for Print, Online Readers. Newspaper Research Journal, 30(3). 105-119.

Mersey, R. D. (2009b). Online News Users' Sense of Society: Is Geography Dead? Journalism Practice, 3(3). 347-360. https://doi. org/10.1080/17512780902798687

Munson, S., Poole, E., Perry, D. B., \& Peyton, T. (2015). Gamification and health. In S. P. Walz (Ed.). The gameful world: Approaches, issues, applications (pp. 597-623). Cambridge, London: MIT Press.

Nelson, J. L. (2018). The elusive engagement metric. Digital Journalism, 6(4), 528-544. https://doi.org/10.1080/21670811.2018.1445 000

Pantic, M. (2017). Active readers: Exploring uses and gratifications of live blogs. American Communication Journal, 19(1), 36-48.

Plèta, T., Tvaronavičienė, M., Della Casa, S. 2020. Cyber effect and security management aspects in critical energy infrastructures. Insights into Regional Development, 2(2), 538-548. https://doi.org/10.9770/IRD.2020.2.2(3)

Pogodina, T.V., Aleksakhina, V.G., Burenin, V.A., Polianova, T.N., Yunusov, L.A. (2019). Towards the innovation-focused industry development in a climate of digitalization: the case of Russia, Entrepreneurship and Sustainability Issues 6(4), 1897-1906. http://doi. org/10.9770/jesi.2019.6.4(25)

Putnam, R. D. (2000). Bowling alone: The collapse and revival of American society. New York: Simon and Schuster.

Roussel, E. (2008). To prepare for the future, skip the present. Nieman Reports, 62 (4), 9-10.

Rubin, A. M. (2009). Uses and gratifications. In the SAGE handbook of media processes and effects. California, CA: Sage Publications.

Ruggiero, T. E. (2000). Uses and gratifications theory in the 21st century. Mass Communication \& Society, 3 (1), 3-37. https://doi. org/10.1207/S15327825MCS0301_02

Sjoblom, M., \& Hamari, J. (2017). Why do people watch others play video games? An $€$ empirical study on the motivations of Twitch users. Computers in Human Behavior, 30(1), 1e12. https://doi.org/10.1016/j.chb.2016.10.019

Smith, B. G., \& Gallicano, T. D. (2015). Terms of engagement: Analyzing public engagement with organizations through social media. Computers in Human Behavior, 53, 82-90. https://doi.org/10.1016/j.chb.2015.05.060

Sridhar, S., \& Sriram, S. (2015). Is online newspaper advertising cannibalizing print advertising? Quantitative Marketing and Economics, 13(4), 283-318. https://doi.org/10.1007/s11129-015-9160-3

Štefko, R., Bačík, R., Fedorko, R., Oleárová, M., Rigelský, M. (2019). Analysis of consumer preferences related to the use of digital devices in the e-commerce dimension, Entrepreneurship and Sustainability Issues 7(1), 25-33. http://doi.org/10.9770/jesi.2019.7.1(2)

Tesařová, M., Krmela, A., Šimberová, I. (2020). Digital support to external sustainability communication in self-adhesive labelling industry. Entrepreneurship and Sustainability Issues, 7(3), 2109-2125. https://doi.org/10.9770/jesi.2020.7.3(44)

Thaker, H. M.T., Khaliq, A., Mand, A. A., Hussain, H. I., Thaker, M. M. T. and Pitchay, A. A. (2020), Exploring the drivers of social media marketing in Malaysian Islamic banks: An analysis via smart PLS approach, Journal of Islamic Marketing, https://doi.org/10.1108/ JIMA-05-2019-0095

Vasilev, V. L., Gapsalamov, A. R., Akhmetshin, E. M., Bochkareva, T. N., Yumashev, A. V., Anisimova, T. I. (2020). Digitalization peculiarities of organizations: a case study. Entrepreneurship and Sustainability Issues, 7(4), 7(4), 3173-3190. https://doi.org/10.9770/ jesi.2020.7.4(39)

Vlasov, A.I., Shakhnov, V.A., Filin, S.S., Krivoshein, A.I. (2019). Sustainable energy systems in the digital economy: concept of smart machines, Entrepreneurship and Sustainability Issues, 6(4), 1975-1986. http://doi.org/10.9770/jesi.2019.6.4(30)

Whiting, A., \& Williams, D. (2013). Why people use social media: A uses and gratifications approach. Qualitative Market Research: An International Journal, 16, 362e369. https://doi.org/10.1108/QMR-06-2013-0041 
Somdech RUNGSRISAWAT is an Associate Professor in Communication and the Vice President for Academic Affairs of Suan Sunandha Rajabhat University, Thailand. His research areas are Communication Arts, Business Administration, and Interdisciplinary Research for Social Sciences.

Thitinan CHANKOSON is an Assistant Professor of Business Administration at the Faculty of Business Administration for Society, Srinakharinwirot University, Thailand. His research areas are International Business Management, Service Business Management, and Supply Chain Management.

ORCID ID: orcid.org/0000-0002-9667-3730

Register for an ORCID ID:

https://orcid.org/register

This work is licensed under the Creative Commons Attribution International License (CC BY).

http://creativecommons.org/licenses/by/4.0/ 